\title{
Julia Bavouzet \\ A Prosopographical Survey of the High Civil Service Corps of the Ministries in the Hungarian Part of the Dual Monarchy
}

\begin{abstract}
Résumé
Cet article est une étude de fond d'un point abordé dans ma thèse, à savoir les modalités de reconversion des élites administratives hongroises au tournant du $\mathrm{XIX}^{\mathrm{e}}$ siècle - élites traditionnelles par excellence - en élite méritocratique battant le fer de la modernité. Le rapport entre professionnalisation et embourgeoisement est à cette occasion interrogé, de façon à apporter un éclairage quantitatif à ces questions. Ainsi, la carrière des 709 hauts fonctionnaires en poste dans les neufs ministères hongrois est mise en regard de leur parcours académique et de leur statut social hérité, de façon à mesurer l'influence du titre universitaire et du titre de noblesse sur la rapidité de l'avancement. On constate alors d'une part la persistance des mécanismes traditionnels dans le recrutement et le système de promotion, qui continue dans une certaine mesure à favoriser l'élite historique au détriment des bourgeois non-titrés, mais aussi d'autre part un investissement croissant de ces mêmes fonctionnaires nobles dans le diplôme universitaire. Avec une mesure fine de ces deux seules variables, la complexité de la reconversion des élites administratives apparaît donc dans toute son ambiguïté.

Ce travail de sociologie historique se veut aussi une illustration des apports heuristiques de la méthode prosopographique, qui connait une certaine désaffection parmi les historiens (en particulier des Habsbug Studies), suite aux excès du quantitativisme des années 1980. Le dialogue avec les autres collaborateurs de l'ouvrage, faisant suite au colloque « The Imperial Austrian Civil Service and its Aftermath, 1848-1933. New Directions of Research: Biography, Social and Organizational History, its Role in Society and Politics », confirme l'importance de ce discours.
\end{abstract}

\section{Mots-clé}

Histoire sociale des élites de l'État: hauts fonctionnaires au XIX ${ }^{e}$ siècle, embourgeoisement et professionnalisation, bureaucratie, prosopographie.

Histoire moderne de l'Europe centrale : histoire politique et sociale de l'Empire austro-hongrois 1867-1918, histoire de la Hongrie XIX ${ }^{\mathrm{e}}$-XX ${ }^{\mathrm{e}}$, formation des intellectuels, élites administratives.

\section{Référence bibliographique}

BAvouzet Julia, «A Prosopographical Survey of the High Civil Service Corps of the Ministries in the Hungarian Part of the Dual Monarchy », Adlgasser Franz, Lindström Fredrik (eds.) : The Habsburg Civil Service and Beyond: Bureaucracy and Civil Servants from the Vormärz to the Inter-War Years, Vienna, Verlag der Österreichischen Akademie der Wissenschaften, 2019, ISBN 978-3-7001-8137-8. 


\section{A Prosopographical Survey of the High Civil Service Corps of the Ministries in the Hungarian Part of the Dual Monarchy}

This essay offers some preliminary results of an on-going prosopographic study of the High Civil Service Corps in the central ministries of Budapest ${ }^{1}$ in the period 1890-1910, with special interest in the ambivalent change in the Hungarian governing elite. At this time, ministerial Konzeptsbeamte, judicially trained civil servants, are at the head of an expanding central administration, which is gradually overtaking the duties of the counties and municipalities, by active centralization politics and homogenization of the different levels of administration. A modern and efficient central bureaucracy, far from being backward, ${ }^{2}$ is emerging in Budapest, based on a more than hundred-year-old tradition of Josephinism perpetuated through the dicasteria ... and yet, nobility is still ruling the state administration. Thereby the High Civil Service Corps embodies par excellence the general trend that is reshaping Hungarian society, the conversion of a traditional feudal elite into a modern one based on the Leistungsprinzip and on competency is certified by a diploma. But it illustrates as well the limits of this conversion taking place. This paper proposes a quantitative approach to try to measure to what extent social status nevertheless remained critical to constituting this new modern elite, even as it is defined somewhat differently than the older one. Indeed, the older estates society, where birth and rank were decisive, evolves into a meritocratic Leistungsgesellschaft but with interesting remnants of feudal forms in the emerging social order, that can be apprehended through the ministry personnel. Konzeptsbeamte of the ministries may have no direct interaction with the civil society, contrary to judges (see Klečacký in this volume), provincial or regional administrators (see Pál, Pokludová, and Wullschleger in this volume), and of course local civil officials (teachers, postal or railway personnel, etc.); still, as Gary B. Cohen phrased it, ${ }^{3}$ they constitute the "public face of the state" and as such, deserve a special attention. Together with the dynasty and the army, state bureaucracy represents the very pillar of the monarchy. High civil servants illustrate this portion of the population that, apart from civil society, can be called the 'official elite' and apprehended as relevant witnesses to specific changes that occurred during this period.

\footnotetext{
${ }^{1}$ In 1890, the central administration of Transleithania was constituted by the Office of the Prime Minister, the Ministry of His Majesty (located in Vienna), and seven specialized ministries: Interior, Finance, Religious Affairs and Education, Justice, Defense, Commerce and Agriculture, the last two created in 1889 through the reorganization of Ministry of Agriculture, Industry and Commerce and the Ministry for Public Works and Transport. In addition to these, the Croatian-Slavonian-Dalmatian Ministry dealt with the special relationship to the Kingdom of Croatia-Slavonia, but due to the particular activities and social composition of its personnel, this ministry is not part of this study. ${ }^{2}$ The theory of Hungary's "backwardness" was elaborated at the beginning of the 1980s by the American scholar Andrew C. Janos (JANOS 1982), who illustrated the anachronism and lack of modernization of Hungarian society, economy and politics from the end of the $19^{\text {th }}$ century on. Yet this theory, now assimilated to a Hungarian Sonderweg, is partly criticized in its theoretical basis, as it oversees the deep evolutions that occurred in the second half of the $19^{\text {th }}$ century. It is however useful to note that the idea of backwardness, of which contemporaries were aware of, is still rooted in many scholarly works and continues to orientate their results. This remark rejoins the conclusive essay of this volume by John Deák, criticizing the historiographical use of the terms 'bureaucratic absolutism' referring to Habsburg bureaucracy, to spread the idea that Austria was an enemy of progress and an historical dead end. See Deák's contribution to this volume.

${ }^{3}$ See Cohen's contribution to this volume.
} 
And yet, very little scholarly interest on this subject can be detected: with the notable exceptions of Gábor Benedek's work, ${ }^{4}$ and more indirectly Eva Somogyi's research on Hungarian leading officials in the common ministries, ${ }^{5}$ the Hungarian central administration is largely overlooked. ${ }^{6}$ On the contrary, it is the county administration that draws most of the scholarly interest, with a wide range of publications more or less emphasizing its role as 'stronghold of the Constitution' against Austrian absolutism - an interest that somehow reveals this "heavy national bias" weighing on the historiography of the successor states, mentioned by Fredrik Lindström in the introduction to this volume ${ }^{7}$. This paper endeavors to remedy this historiographical lack as well as to propose further perspective of research on Hungarian Ministerialbeamte, especially regarding the input of quantitative methods (prosopography) in a field largely dominated by collective biographies or focus on individual civil servants.

According to the contemporary legislation, ${ }^{8}$ civil servants of the ministries were categorized in eleven ranks (labelled with Roman numbers), associated with a hierarchical position, salary and requisite competences. The top three ranks (Prime Minister, Ministers, State Secretaries) were reserved for political functionaries. Rank IV constitutes an exception, as it concerns members of the High Court; they do not appear in this study. This survey extends to the positions of Ministerial-Rat (miniszteri tanácsos, rank V), Sektions-Rat (osztálytanácsos, rank VI), and Ministerial-Sekretär (miniszteri titkár, rank VII), as they form together the bureaucratic elite. ${ }^{9}$ From rank VI up, officials were nominated jointly by the minister and the king. In many ways, rank VI constitutes an implicit dividing line between the highest members of the administration and the other Konzeptsbeamte, as it was the threshold to being admitted to court or receiving the honorary distinctions of Geheimer Rat (v. b. titkos

\footnotetext{
${ }^{4}$ BENEDEK 1990 and 2010.

${ }^{5}$ SOMOGYI 2002 and 2010.

${ }^{6}$ According to Judit Pál, it is the Hungarian administrative elite of the $19^{\text {th }}$ century in general that is facing a lack of historiographical interest, as opposed to economic, military and church elite. And even among this administrative elite, the central bureaucracy is the most overlooked, as can be concluded from the bibliographical references she lists. See Pál's contribution to this volume.

${ }^{7}$ From my own research about the Hungarian administration during the dualist era, I must agree with Lindström's statement on the differences between Austrian and Hungarian historiographies regarding the subject of Habsburg administration (see Lindström's contribution to this volume). Indeed, Hungarian scholars of the administration show little interest in the imperial legacy, with the notable exception of Somogyi's work on the common imperial (gesamtstaatlichen) institutions and her involvement in the edition of Die Protokolle des gemeinsamen Ministerrates der österreichischungarischen Monarchie 1867-1918. See SOMOGYI 1996. On the contrary, Hungarian historiography focuses exclusively on Hungarian history strictly speaking: counties administrated by the Magyar nobility, magyarization politics led by representatives of local authorities, and professionalization of several branches of technical administration (such as railways, posts and telegraphs, mines, etc.), all paying attention to linguistic and national issues.

${ }^{8}$ See Corpus Juris Hungarici: Law 1893:IV on the salary of the state civil servants, lower officials and servants. This law concerns the personnel of the ministries, but not that of the counties. In spite of their repeated claims, county officials were not categorized in the same ranking system until 1904.

${ }^{9}$ The top regional administrators, Lord Lieutenants (fóispán, Obergespan) and Deputy Lord Lieutenants (alispán, Vizegespan) also belonged to the ranks V and VI, but are not included in this study. Lord Lieutenants represented the government's authority in the counties. As other ministerial officials of these ranks, they were directly appointed by the minister and the king. By contrast, Deputy Lord Lieutenants were elected by the counties, and officiated as the heads of the autonomous local administration.
} 
tanácsos) and Kämmerer (kamarás). ${ }^{10}$ Still, Ministerial-Sekretäre are included in this study, as they were also directly appointed by the king ${ }^{11}$ and could hold leading functions such as department head (osztályvezetö, Sektions-Leiter), which were in fact dissociated from the rank. Rank VII appears thus to constitute the real border between leading and executing positions.

The study sample therefore consists of the 709 senior officials on duty between 1890 and 1910 in the nine Hungarian ministries mentioned above (Table 1). Their names, hierarchical positions and titles can be found in the volumes of the Hof-und Staats-Handbuch der österreichisch-ungarischen Monarchie ${ }^{12}$ verified by the lists compiled by Vera Székely. ${ }^{13}$ The Staatshandbücher thus provide two major information, namely noble and academic titles, which will be the main variables the present statistical study proposes to measure. Further information was collected in various, mostly second-hand sources, like biographical lexica, ${ }^{14}$ university databases ${ }^{15}$ and registers ${ }^{16}$, but also in funeral notices ${ }^{17}$ that provide valuable information on denomination and family connections - information that is otherwise difficult to access. Personnel records of civil servants, the so-called minösitési lapok or DienstTabellen which would provide the same information but from a unique homogeneous source, are unfortunately unavailable, presumably destroyed during the multiple war episodes of the $20^{\text {th }}$ century.

Table 1: Distribution of High Civil Servants, 1890-1900

\begin{tabular}{|c|c|c|c|c|}
\cline { 2 - 5 } \multicolumn{1}{c|}{} & rank VII & rank VI & rank V & Konzeptsdienst \\
\hline 1890 & 118 & 92 & 42 & 405 \\
\hline 1895 & 103 & 105 & 48 & 451 \\
\hline 1900 & 112 & 111 & 53 & 520 \\
\hline 1905 & 116 & 122 & 62 & 535 \\
\hline
\end{tabular}

${ }^{10}$ See GYÁNI \& KÖVÉR 2006.

${ }^{11}$ The joint nomination by minister and king also applied to ministerial secretaries, even if they were categorized in rank VII (at least until 1896). IVÁNYI 1960, 531.

${ }^{12}$ For the purpose of this study, I used both the Austrian (Hof- und Staats-Handbuch der österreichisch-ungarischen Monarchie) and the Hungarian version (Magyaroszág tiszti cim-és névtára.). Indeed, the Austrian version is more precise regarding the nobility of civil servants (lesser nobility is mentioned by the preposition "v.", whereas noble predicates don't systematically appear in the Hungarian version). Beside the noble title, the Staatshandbücher also mention doctorates, J. Dr. or Dr. rer. pol. for Law or Political Sciences, M. Dr. or Chir. Dr. for Medicine or Surgery, Ph. Dr. for Philosophy and finally $T h$. Dr. for Theology. Engineers did not receive doctoral degrees before 1902, and therefore appear without academic degrees. The major value of this source is its annual publication, allowing to retrace year-by-year the structural composition of the Konzeptsdienst, as well as every individual career-path. See also NOFLATSCHER 2007.

${ }^{13}$ See SZÉKELY 1979-1985.

${ }^{14}$ See RÉvai NAGY LEXIKONA 1911-1935. SZINNYEI 1891-1914. KENYERES 1967.

15 "University databases realized under the direction of V. Karády et P. T. Nagy thanks to the international project ELITES08 of the European Research Council." I would like to thank Prof. Karády who kindly allowed me to search my senior officials in these databases.

${ }^{16}$ The collection of Magyarországi diákok edited by László Szögi contains information about student registers of all Hungarian students in universities abroad. For this particular study, the following publications were consulted: SZÖGI \& KISS 2003; SzÖGI et al. 2014; PATYI et al. 2015. As for the use of registers of students (matriculae) as a source for quantitative study, see HADOBÁs 2008.

${ }^{17}$ Funeral notices edited between 1840 and 1990 are conserved at the Széchenyi National Library in Budapest. A digital version is also available on familysearch.org, in a database that contains more than half a million funeral notices. 


\begin{tabular}{l|l|l|l|l|}
1910 & 132 & 147 & 85 & 538 \\
\hline
\end{tabular}

\section{State prestige and bureaucracy: a traditional elite}

Social composition of the Konzeptsdienst helps us enlighten the specificities of this elite in relation to the whole population as well as to other elite-groups. Since the admission of commoners in all administrative levels (1848), nobles were no longer the only ones to embody state power. Yet state bureaucracy was still largely managed by the nobility. Did the senior officials as a group not symbolize par excellence an archetype of the traditional social elite, due to the functions and the social backgrounds of its members? A first approach to answer this question would be to consider the social composition of senior officials in the Konzeptsdienst regarding the proportion of nobility. Among the 709 senior officials of this survey, $466(66 \%)$ possess a title of nobility whereas $243(34 \%)$ are non-titled commoners. As obvious as this result might be, raw statistics prove to be somehow misleading. First they don't show the real composition of the Konzeptsdienst at a specific time, but consider the group of senior officials recruited during a time-lapse of 20 years. And second, they don't take into account the seniority of the titles (Table 2).

Table 2: Social composition of the Konzeptsdienst, 1890-1918 18

\begin{tabular}{|l|c|c|c|c|c|c|c|}
\cline { 2 - 8 } \multicolumn{1}{c|}{} & 1890 & 1895 & 1900 & 1905 & 1910 & 1915 & 1918 \\
\hline Non-titled & $\mathbf{3 5 \%}$ & $\mathbf{3 8} \%$ & $\mathbf{4 1} \%$ & $\mathbf{4 1} \%$ & $\mathbf{3 9} \%$ & $\mathbf{4 5} \%$ & $\mathbf{4 6} \%$ \\
\hline Lesser nobility & $\mathbf{6 1} \%$ & $\mathbf{5 8} \%$ & $\mathbf{5 6} \%$ & $\mathbf{5 5} \%$ & $\mathbf{5 8} \%$ & $\mathbf{5 2} \%$ & $\mathbf{5 1 \%}$ \\
\hline new nobles* & $52 \%$ & $48 \%$ & $44 \%$ & $44 \%$ & $45 \%$ & $38 \%$ & $37 \%$ \\
\hline ennobled & $7 \%$ & $7 \%$ & $9 \%$ & $8 \%$ & $9 \%$ & $10 \%$ & $8 \%$ \\
\hline Aristocracy & $1 \%$ & $3 \%$ & $3 \%$ & $3 \%$ & $4 \%$ & $4 \%$ & $5 \%$ \\
\hline old aristocracy & $\mathbf{4 \%}$ & $\mathbf{4 \%}$ & $\mathbf{3} \%$ & $\mathbf{4 \%}$ & $\mathbf{4 \%}$ & $\mathbf{2} \%$ & $\mathbf{4 \%}$ \\
\hline new aristocrats* & $3 \%$ & $3 \%$ & $2 \%$ & $4 \%$ & $3 \%$ & $1 \%$ & $1 \%$ \\
\hline ennobled in the aristocracy & $1 \%$ & $0 \%$ & $0 \%$ & $0 \%$ & $1 \%$ & $1 \%$ & $2 \%$ \\
\hline TOTAL & $0 \%$ & $1 \%$ & $1 \%$ & $1 \%$ & $1 \%$ & $1 \%$ & $1 \%$ \\
\hline
\end{tabular}

* The categories "new nobles" and "new aristocrats" refer to individuals whose father or grandfather has been ennobled. They have thus inherited a title of nobility, but recently acquired. They have to be distinguished from the historic old nobility, whose titles date sometimes back to the $12^{\text {th }}$ century.

The social composition of the Konzeptsdienst reveals a majority of nobles throughout the Hungarian Monarchy, even if it declined from $61 \%$ in 1890 to $51 \%$ in 1918. If we add the contingent of aristocrats to the lesser nobility, traditional orders constituted undeniably more than half of the Konzeptsbeamte. This points out some specific differences with the Viennese bureaucracy, where the aristocracy was still more dominant (14\% against $4 \%$ in Budapest), but also the non-titled commoners more largely represented (57\% against $47 \%$ in

\footnotetext{
${ }^{18}$ In order to identify nobles and aristocrats with an acceptable degree of certainty, every surname was checked in the volumes of Béla Kempelen's register of noble families in Hungary. This register also provides information about the anciennety of these letters of nobility, what allows to distinguish the old nobility from the new one. KEMPELEN 1911. As for the ennobled civil servants, names, titles and dates are drawn from Magyar Orszságos Levéltár, MOL K-19, Király Személye Körüli Minisztérium Levéltára - Libri Regii - Királyi könyvek. http://adatbazisokonline.hu/en/adatbazis/a-57_-k-19-libriregii-\%C2\%B7-kiralyi-konyvek-1527\%E2\%80\%941918 (accessed 1 February 2018).
} 
Budapest). ${ }^{19}$ Yet this conclusion must be moderated if we consider the seniority of the titles of nobility. Indeed, the various new groups of lesser nobility in Hungary formed a transitional stage between the older nobility and commoners, and should therefore not be considered at the same level as the older nobility or the aristocracy. The historical orders (old nobility along with old aristocracy) still accounted for more or less $60 \%$ until 1910, but this rate drastically declined to $38 \%$ during the First World War, as the proportion of commoners caught up with that of the nobility. This relative switch towards the middle classes is made even clearer when we consider the large number of newly ennobled civil servants who obtained their title during their service. Indeed, the proportion of more recently ennobled civil servants, the Beamtenadel, grew inside of the Konzeptsdienst, (9-10\% until 1900, and then 15-16\% during the war). We will pay special attention to this group in the following. As for non-titled commoners, their proportion rose by $5 \%$ at the turn of the century, and again $5 \%$ during the war. They might account only for $34 \%$ of all senior officials in duty between 1890 and 1910, but due to turnover in the ministry personnel they always exceeded this proportion in the Konzeptsdienst.

Regarding these figures, the new trend can be seen even in the short time-span of twenty years: despite the high proportion of traditional orders, the Konzeptsdienst is effectively experiencing a gentrification (or Verbürgerlichung) of its social composition. If the proportion of commoners alone has not reached the symbolic barrier of $50 \%$, when added to the ennobled (i.e. born as non-nobles), they do exceed half of those in duty during the First World War. These considerations rejoin the actual scholarly consensus regarding the Verbürgerlichung of the administrative personnel. Janos proposed similar results, although quite overestimating the proportion of commoners $(60 \%$ of nobles in 1890 but only $49 \%$ in 1910). ${ }^{20}$ Benedek also points out the increasing proportion of commoners in ministerial bureaucracy, ${ }^{21}$ revealing thereby the actual historiographical tendencies aiming to pinpoint the various manifestations of the Verbürgerlichung process and emphasizing the role of the Bildungsbürgertum. These new tendencies deserve special mention, as administration was usually described as the traditional elite par excellence, stronghold of the archaic gentry who tried to maintain its privileges. ${ }^{22}$

${ }^{19}$ See in the table below the social composition of the high civil service corps in the ministries of Vienna and Budapest, 1900-1910:

\begin{tabular}{|c|c|c|c|c|}
\cline { 2 - 5 } \multicolumn{1}{c|}{} & \multicolumn{2}{c|}{ Budapest } & \multicolumn{2}{c|}{ Vienna } \\
\hline Traditional orders* & 179 & $53 \%$ & 157 & $43 \%$ \\
\hline Aristocracy & 14 & $4 \%$ & 53 & $14 \%$ \\
\hline Lesser nobility & 165 & $49 \%$ & 104 & $29 \%$ \\
\hline Non-titled & 157 & $47 \%$ & 205 & $57 \%$ \\
\hline TOTAL & $\mathbf{3 3 6}$ & $\mathbf{1 0 0} \%$ & $\mathbf{3 6 2}$ & $\mathbf{1 0 0} \%$ \\
\hline
\end{tabular}

* Ennobled civil servants, the Beamtenadel, figure among the lesser nobility, as they do have a title of nobility and thus cannot be counted as non-titled. However, in Budapest, they represent these critical $3 \%$ that make the majority of traditional order among the Konzeptsdienst.

For the Viennese bureaucracy, the numbers are drawn from URBANITSCH 2008, 205. For Budapest, my database was adjusted accordingly. Peter Urbanitsch scrutinizes only the Sektionschefs (rank IV), Ministerial-Räte and Hofräte (rank V), but not the Ministerial-Sekretäre (rank VI). In Hungary, aristocrats appeared in the more political functions such as ministers (half of the ministers in the Dualist era), Lord Lieutenants (two thirds during the whole period) and state secretaries; whilst their proportion among civil servants is significantly less than the corresponding rate in Vienna. By contrast, nobles composed half of the personnel under consideration in Hungary, but only one third in Austria. One explanation for the high proportion of the nobility in the administration is the much higher percentage of nobles within the Hungarian lands, making up 5\% of the total population.

${ }^{20}$ See JANOS 1982, 110.

${ }^{21}$ See BENEDEK 1990.

${ }^{22}$ For example, Ernő Lakatos asserted in his famous study on the Hungarian governing elite that the gentry accounted for two-thirds of the central administration. He also concluded that "noble 
Table 3: Proportion of nobility in the ministries, 1890-1910

\begin{tabular}{|l|c|c|c|c|c|c|}
\cline { 2 - 6 } \multicolumn{1}{c|}{} & TOTAL & Non-titled & Titled* & $\begin{array}{c}\text { Historical } \\
\text { orders }\end{array}$ & $\begin{array}{c}\text { New } \\
\text { nobles }\end{array}$ & Ennobled \\
\hline Office of Prime Minister & 29 & $38 \%$ & $62 \%$ & $45 \%$ & $3 \%$ & $14 \%$ \\
\hline Ministry of His Majesty & 12 & $8 \%$ & $92 \%$ & $58 \%$ & $8 \%$ & $25 \%$ \\
\hline Interior & 130 & $40 \%$ & $60 \%$ & $49 \%$ & $5 \%$ & $5 \%$ \\
\hline Religous Affairs and Ed. & 59 & $29 \%$ & $71 \%$ & $58 \%$ & $8 \%$ & $5 \%$ \\
\hline Justice & 46 & $37 \%$ & $63 \%$ & $37 \%$ & $13 \%$ & $13 \%$ \\
\hline Finance & 169 & $40 \%$ & $60 \%$ & $43 \%$ & $9 \%$ & $8 \%$ \\
\hline Commerce & 138 & $30 \%$ & $70 \%$ & $49 \%$ & $10 \%$ & $11 \%$ \\
\hline Agriculture & 111 & $17 \%$ & $83 \%$ & $60 \%$ & $9 \%$ & $14 \%$ \\
\hline Defense & 56 & $39 \%$ & $61 \%$ & $46 \%$ & $4 \%$ & $11 \%$ \\
\hline TOTAL & $\mathbf{7 0 9}$ & $\mathbf{3 4} \%$ & $\mathbf{6 6} \%$ & $\mathbf{4 8 \%}$ & $\mathbf{8 \%}$ & $\mathbf{1 0} \%$ \\
\hline
\end{tabular}

* The category 'titled' refers to both aristocracy and lesser nobility.

Also discrepancies between the ministries are to be observed (Table 3). The essentially representative Ministry of His Majesty was almost exclusively composed of nobles (92\%), whereas nobility accounted only for two-thirds in more specialized ministries like Finance, Interior, Justice or Defense. On the contrary, the traditionalist Ministry of Agriculture had the highest proportion of historical orders $(60 \%)$ as well as of ennobled (14\%), and the lowest proportion of non-titled persons or commoners (17\%) - with the exception of the Ministry of His Majesty. The social differentiation of the ministries thus does not correspond to their range of duties. This is especially the case of the technical ministries (Finance, Commerce and Agriculture), though they are often assimilated to one another. For example, Janos asserted that they were all 'bourgeois' ministries, as the members of the gentry were forced to compete with outsiders, especially in the more 'technical' fields of commerce and finance. However, while the ministry of Finance presented indeed a high rate of non-titled officials $(40 \%)$, on the contrary Commerce and Agriculture were far less open to commoners (17-30\%). Moreover, presuming that technical fields of the administration shall easily welcome nonnoble Konzeptsbeamte contributes to transport the impression that technicization and professionalization should necessarily go with broadening the social recruitment - according to the relation between Verbürgerlichung and Professionalisierung theorized by Max Weber. Yet we shall somehow revise this statement in the following, or at least temperate it in the case of ministerial bureaucracy.

Still, it is quite difficult to evaluate the significance of noble titles inside the bureaucracy. ${ }^{23}$ Social sparkle of an old family name may be shattered by poor financial conditions. Besides, the asset that a noble name could offer at the beginning of a career (family connections, protection) ${ }^{24}$ would not guarantee a rapid promotion in the upper ranks

landowners' representation in executive branches has always been significant, yet a slow but constant decrease was to be observed. Among leading positions on the contrary, they were proportionally overrepresented, and thereby they completely determined the sociological compositions of some ministries, especially the Office of Prime Minister, the Ministry of The Interior and the Ministry of Agriculture." LAKATOS 1942, 63. While for Lakatos, the Ministries of the Interior and Agriculture and the Office of the Prime Minister were the most 'noble' ones, this somehow differs from the results of this study (see Table 3) and reveals his perception of the representative (versus technical) ministries. ${ }^{23}$ These considerations are also to be found in Pokludová's contribution to this volume.

${ }^{24}$ Indeed, the careers of the previous generation still had a major influence on the chances of success of their offspring. The fathers of $40 \%$ of the noble high civil servants also worked or had worked in the administration, and self-recruitment led to the formation of dynasties of civil servants. See BENEDEK 2010, 1226. The fathers of several high civil servants under consideration in this sample 
of the Konzeptsdienst, strictly regulated by seniority (the so-called szamárlétra). Statistical analysis may prove to be useful here, by providing quantitative insights into the promotion mechanism, beyond the legal norms aiming to rationalize and homogenize the bureaucratic machinery.

Table 4: Career expectations according to the title of nobility, 1890-1910

\begin{tabular}{|l|c|c|c|c|c|c|}
\cline { 2 - 7 } \multicolumn{1}{c|}{} & TOTAL & Non-titled & Titled* & $\begin{array}{c}\text { Historical } \\
\text { orders }\end{array}$ & $\begin{array}{c}\text { New } \\
\text { nobles }\end{array}$ & Ennobled \\
\hline$M-R$ (V. rank) & $47 \%$ & $35 \%$ & $53 \%$ & $49 \%$ & $57 \%$ & $73 \%$ \\
\hline$S-R$ (VI. rank) & $78 \%$ & $73 \%$ & $80 \%$ & $78 \%$ & $81 \%$ & $87 \%$ \\
\hline$M-S$ (VII. rank) & $85 \%$ & $84 \%$ & $86 \%$ & $87 \%$ & $91 \%$ & $77 \%$ \\
\hline TOTAL & 709 & 243 & 466 & 338 & 58 & 70 \\
\hline
\end{tabular}

Table 5: Age at the time of promotion in the higher ranks according to the title of nobility, 1885-1918 ${ }^{25}$

\begin{tabular}{|c|c|c|c|c|c|c|c|c|c|c|c|c|}
\hline & \multicolumn{3}{|c|}{ VII. Ministerial-Seketäre } & \multicolumn{4}{|c|}{ VI. Sektions-Räte } & \multicolumn{3}{|c|}{ V. Ministerial-Räte } \\
\cline { 2 - 14 } & Average & $\begin{array}{c}\text { Non- } \\
\text { titled }\end{array}$ & Titled* & Ennobled & Average & $\begin{array}{c}\text { Non- } \\
\text { titled }\end{array}$ & Titled* & Ennobled & Average & $\begin{array}{c}\text { Non- } \\
\text { titled }\end{array}$ & Titled* & Ennobled \\
\hline $1886-1895$ & 37 & 38 & 36 & 37 & 43 & 46 & 42 & 42 & 50 & 50 & 50 & 52 \\
\hline $1896-1905$ & 39 & 40 & 38 & 41 & 45 & 46 & 45 & 45 & 51 & 52 & 49 & 52 \\
\hline $1906-1918$ & 39 & 39 & 39 & 38 & 45 & 46 & 44 & 47 & 51 & 51 & 52 & 51 \\
\hline
\end{tabular}

Table 4 measures the career expectations of senior officials in relation with their social background. It shows clearly that members of the historical orders, may they belong to the lesser nobility or the aristocracy, had better chances to reach the top rank of Ministerial-Rat than non-titled commoners (49\% against $35 \%$ ). Yet the ennobled civil servants are the most likely to make it to rank V (73\%), as they precisely constitute the elite of the Konzeptsdienst, ennobled as reward for their services rendered to the state during their career. Indeed, noble titles represented a valuable social asset in paving the road to the highest posts in the administration. But once again, this first observation must be tempered by scrutinizing the age of civil servant as they get promoted to a higher rank (Table 5). This time, it seems that nobility does not help to reach the top of the hierarchy faster: commoners as well as nobles have to go through the same career ladder, one step after another. If noble titles proved to be an asset for recruitment (Table 2) and career expectations (Table 4), the rapidity of the advancement shows no correlation with the social status at the turn of the century.

worked in the very same ministries (Abrányi, Emich, Fejér, Hollán, Kenessey, Splényi, Torkos) or in county administrations (e.g. as alispán/Vizegespan: Berczik, Bezerédj, Ferdinandy, Madách, Majovszky, Ottlik, Péchy, Széll, Szüry, all of them nobles). The administration was also an endogamous world: civil servants married the daughters or sisters (Buday, Koós, Lukács, Petróczy) of their colleagues. In the case of Mihály daruvári Kacskovics, who worked in the Ministry of Religious Affairs and Education and whose family was ennobled in the first half of the $19^{\text {th }}$ century, his two sisters married high civil servants in the same ministry and in service during the period under consideration: Ödön bonczházi Boncz and Ferencz szakátsi Csorba. Also two of Kacskovics's brothers served as a Ministerialrat and a Deputy Lord Lieutenant, respectively. These familial strategies offer a glimpse into the practices of patronage and protection, which inevitably occurred, even though they are rather difficult to identify. Family ties and recommendations undoubtedly played a role in obtaining a post, or passing through each stage more quickly.

${ }^{25}$ Calculation made from the Tiszti Cimtár and the various biographical sources cited above (for the date of birth). Only the promotions that occurred during the period under consideration were taken in account. 
Yet, this relative move towards the middle classes that occurred at the turn of the century should not hide the fact that the closed micro-world of the High Civil Service Corps was still deeply rooted in traditional thinking: state prestige is still identified with the historical elite. To gauge this prestige, we should recall that rank VI acted as a symbolic limit, determining access to the Imperial and Royal court, giving Hoffähigkeit (udvarképesség) to their bearers, even if they were not members of the aristocratic 'first society' (elsö társadalom). Obviously, bureaucratic rank corresponds to the hierarchical position occupied in the Konzeptsdienst, but as we saw, it also expresses the social status this position assured. The ranking system thus offers a specific argument to enlighten the conversion of inherited status into acquired position, and deserves here a special mention. For example, besides their salary ${ }^{26}$ which is quite normally increasing with hierarchy (and seniority), state officials enjoyed several privileges and allowances according to their rank. Moreover, the very meaning of these privileges was to reflect and emphasize the rank. For example, housing allowance (lakpénz) varying from 600 to $1,000 \mathrm{ft}$. was granted for state officials from the ranks VII-V living in Budapest (the most expensive city in the country), to allow them to live 'according to their rank' (rangmäßig - rangszerü). This appears even more clearly in the case of accommodation, when every rank was allowed a defined number of rooms: MinisterialRäte and Sektions-Räte were allowed to rent a five-room apartment in Buda or a four-room one in Pest, however Sekretäre only four rooms in the $1^{\text {st }}$ and $2^{\text {nd }}$ districts in Buda or three in Pest. According to the 1874 regulation on the financial service, these measures were explicitly intended to enable individuals to afford appropriate living quarters, in keeping with their social status. Also in the case of traveling, this regulation stipulates the right to travel in carriages drawn by two, three, four, or even six horses, or to travel first or second class in trains and tramways, depending on the rank. ${ }^{27}$ Even heating and lightning allowances at the office are determined by the rank. In other words, beyond the office, the salary rank actually corresponded to a social rank: the hierarchical position in the Konzeptsdienst conferred a social status and its commensurate prestige. These social historical considerations rejoin Therese Garstenauer's more developed analysis on Austrian civilian government employees' conduct of life (standesgemäße Lebensführung) ${ }^{28}$ as well as Waltraud Heindl's research on living standards, domestic culture and habitus of Austrian civil servants; ${ }^{29}$ they can only be mentioned here without proper extension, especially as this field remains largely to be researched in the case of Hungarian civil service. ${ }^{30}$

\footnotetext{
${ }^{26}$ According to Hungarian Law 1893:IV, the salaries in rank VII varied between 2,000 ft (Gulden, Forint) and 2,400 ft, in rank VI between 2,500 and 3,000 ft, and in rank V between 4,000 and 5,000 ft (plus 500-1,000 ft each for housing allowance). Considering that the symbolic barrier for middle-class standard of living was 3,000 ft, the salaries of Ministerial-Räte as well as Sektions-Räte guaranteed them upper middle class standards of living, even if they had no additional income (land, properties, etc.). HAJDÚ 1999, 240-246.

${ }^{27}$ A magyar királyi Pénzügyminisztérium ügykörre vonatkozó szolgálati szabályok gyüjteménye (1874), cited by LADIK 1908, 220. With accommodation becoming more and more expensive, the housing support was not sufficient to meet the standards requested. Several complaints show the bitterness of senior officials who, although living quite decently compared with other professions, feared social decline.

${ }^{28}$ See Garstenauer's contribution to this volume,.

${ }^{29}$ HEINDL 2013b.

${ }^{30}$ As I mentioned before, Hungarian central administration does not benefit from a long historiographical tradition. Some issues are present in Benedek's work, for example regarding housing and estate properties. See BENEDEK 2009. As for leisure activities, matrimonial strategies, social role of wives, education of children (all aspects treated by W. Heindl), these domestic aspects of civil servants remains to be searched on.
} 
Terms of address present a specific issue, as this bureaucratic practice emanates from nobility, and encompasses the whole public sphere of society. Terms of address should be seen as remnants of the feudal system of rank and order (nemes-rendi), where the hierarchy of the aristocracy actually corresponded to the hierarchy of offices. The inherited status (of the nobility) was then transformed into an individual position (in the bureaucracy), but the forms of address remained associated with certain virtues, as well as moral and intellectual qualities. Distinct terms of address were thus attributed according to rank, which were strictly observed when addressing superiors. For example, ministers were bearing the title of 'excellenciás úr' ('your excellency'), and Ministerial-Räte 'méltoságos úr' ('your worship'). At rank VI, SektionsRäte were called 'nagyságos úr' ('your honour'), but Ministerial-Sekretäre were only 'tekintetes úr' (approximately translated as 'the most noble'), emphasizing the hierarchical position of individuals in the bureaucratic apparatus. But these terms of address also reveal a person's position in the social hierarchy, as the social prestige they carry goes beyond the strictly professional sphere. A university professor, for example, who may have earned more than a Ministerial-Rat (rank V) thanks to the course fees, was still only addressed as nagyságos úr and considered less prestigious, as he belonged to rank VI. In this sense, Gábor Gyáni and György Kövér are elaborating new methods to delimit the social elite based on terms of address. ${ }^{31}$ These results could contribute to a better comprehension of the relationship between state officials and society. Indeed, terms of address worked as a common standard, allowing the prestige of each profession (categorized in the ranking system) and each individual (may they be civil servants, but also university graduates, aristocrats or members of the royal orders) to be measured. As for senior officials themselves, further research on their specific use of bureaucratic titles and terms of address might help us to better evaluate status and prestige among various social spheres. ${ }^{32}$

In many respects, the turn of the century seemed to be a turning point in the High Civil Service Corps. Not only did non-titled senior officials surpass the nobility (not counting the aristocracy) in absolute numbers, but also noble titles became less significant for career advancement. This is also the time when major laws were promulgated, in order to rationalize and professionalize state administration (Laws 1883:I on qualification and recruitment, 1885:XI on pensions, 1893:IV on salary). Besides, the arrival of a new generation of civil servants, entering the administration in the 1880s and reaching higher functions around 1900, was largely responsible for the increase of senior officials (from 405 in 1890 to 538 twenty years later, see Table 1 above). ${ }^{33}$ This leads to the hypothesis that a general shift towards the

\footnotetext{
${ }^{31}$ See GYÁNI \& KÖVÉR 2006.. For the social meaning of the different terms of address and their role as a gauge of prestige, see KOVÁCS 2011. Some groups were not included in the hierarchy of prestige as defined by terms of address, as they evolved separately from the ranking system, like the private financial and industrial spheres, liberal professions and the new professional groups which developed alongside capitalism. Their members were usually addressed as úr' (Sir).

${ }^{32}$ A person might pretend to various terms of address, due to his multiple affiliations. Count Gedeon Ráday, for example, should have been addressed as nagyságos úr according to the bureaucratic hierarchy, as he was Sektionsrat at the Interior Ministry. But as an aristocrat, he stuck to the more prestigious méltóságos úr. However, later in his career, he choosed to use his bureaucratic title to emphasize his hierarchical position. See CSAPÓ 2002. Two kinds of hierarchies existed side by side and complemented each other. The strategy thus consisted in using the appropriate title at the right time, according to what was considered more prestigious in the respective situation.

${ }^{33}$ Indeed, huge changes occurred among ministerial Konzipisten (rank IX) in the 1880s. Following a great reduction in their number in the 1870s due to economic straits on the part of the state, they soon doubled the number of senior civil servants. The impact of this nouvelle garde on ministerial personnel is yet to be examined. See composition of the lower ranks of the Konzeptsdienst, 1873-1891 (numbers drawn from BENEDEK 1997, 110):
} 
middle classes occurred due to the arrival of a new generation, and that elite conversion was rather an elite replacement.

\section{A meritocratic elite}

The needs of a modern bureaucracy for competent and professionalized personnel in the Habsburg Monarchy generated a long tradition of regulations going back to the late $18^{\text {th }}$ century, which culminated in the qualification law (minösitési törvény) of $1883 .{ }^{34}$ The new law required a specific formal qualification for each administrative post, which allowed "if not to hire the most competent, at least to have only competent individuals." 35 Higher officials of the central administration were thus expected to have at least completed their studies in Law or Political Science at the universities in Pest or Kolozsvár (Klausenburg / Cluj), or at a law academy, and passed the Staatsprïfung (államvizsga) or obtained a doctoral degree. ${ }^{36}$ The bar examination to practice law, which apparently did not certify any administrative competence, was also regarded as an adequate qualification for a career in the ministries. Yet one could not talk about a Juristenmonopol as in Prussia, which in 1879 made a law degree compulsory for entrance to the higher civil service. Indeed, besides the traditional law-trained Konzeptsbeamte, the qualification law reserved some functions for members of other professions (engineers at the land registry, physicians at the Health Department in the Interior, teachers in the Ministry of Religious Affairs and Education, etc.). In addition, engineers were authorized to join the administration after passing a special law and administrative exam, but they could only obtain certain professional posts, such as Technischer Rat (müszaki tanácsos), Kulturbeamter (kultúrmérnök) or positions in the accounting offices. The qualification law thus contributed to the rise of experts in the central bureaucracy.

Taking into account the time lag and the fact that legal requirements often differed from the effective reality of bureaucratic practices, the turn of the century appears to be the proper time to measure the impacts of the qualification law. Senior officials in service in the 1890s had usually entered the administration before 1883, but the generation at the top of the hierarchy in 1910 had been recruited after the proclamation of the law. As academic titles were listed next to the name, the Staatshandbücher offer a first overview of the presence of doctorates in the ministries, while lesser qualifications (Staatsprüfung, lawyer's license, engineer's degree), rarer, are far more difficult to detect and therefore not considered here.

\begin{tabular}{|l|c|c|c|c|}
\cline { 2 - 5 } \multicolumn{1}{c|}{} & 1873 & 1879 & 1884 & 1891 \\
\hline Ranks V.-VII. & 235 & 208 & 216 & 228 \\
\hline Ranks VIII.-XI. & 336 & 153 & 307 & 372 \\
\hline TOTAL & 571 & 361 & 523 & 600 \\
\hline
\end{tabular}

${ }^{34}$ From Maria Theresa's recommendations and Joseph II's Hirtenbrief to the more detailed instructions of the $19^{\text {th }}$ century, civil servants had to go through legal education in law academies or universities. See BENEDEK 2003. The qualification Law was passed as a result of an enquiry into the state personnel, initiated by Prime Minister Tisza, in order to find a remedy to the 'Asian condition' ('ázsiai állapot') of the Hungarian administration. This recurrent critic, referring to an imagined underdeveloped Asia as opposed to the modern West, is due to deputy Pál Szennyey, who deplored during his first session in the Parliament in 1872 the poor state of administrative structures, and appealed to fundamental reforms of the county administration. See JANOS 1982, xxi.

${ }^{35}$ BENEDEK 2003. The political functions of minister, state secretary and Lord Lieutenant were not defined by any compulsory qualifications, as, in the public opinion of the time, those prerequisites would have restricted the 'free' and 'democratic' choice for these leadership positions.

${ }^{36}$ In 1872, the Kolozsvár Law Academy was re-organized into a second Hungarian university. The four law academies were situated in Pozsony, Kassa (Kaschau, Košice), Nagyszeben (Hermannstadt, Sibiu) and Nagyvarad (Großwardein, Oradea). For an overview of legal training in Hungary in the $19^{\text {th }}$ century, see KARÁDY 1991, 106-108, and BAVOUZET 2017, 207-271. 
Doctors represent $36 \%$ of our sample (256 individuals), but as in the case of noble titles, finer statistical analyses must be conducted.

Table 6: Proportion of doctors in the Konzeptsdienst, regarding noble titles, 1890-1918

\begin{tabular}{|l|c|c|c|c|c|c|}
\cline { 2 - 7 } \multicolumn{1}{c|}{} & $1890-1894$ & $1895-1899$ & $1900-1904$ & $1905-1909$ & $1910-1914$ & $1915-1918$ \\
\hline TOTAL & 319 & 366 & 351 & 434 & 505 & 516 \\
\hline doctors & 64 & 96 & 117 & 186 & 260 & 321 \\
\hline Proportion of doctors & $\mathbf{2 0} \%$ & $\mathbf{2 6} \%$ & $\mathbf{3 3} \%$ & $\mathbf{4 3} \%$ & $\mathbf{5 1} \%$ & $\mathbf{6 2} \%$ \\
\hline Titled & 226 & 256 & 234 & 281 & 316 & 283 \\
\hline doctors & 41 & 67 & 77 & 123 & 167 & 184 \\
\hline Proportion of doctors & $\mathbf{1 8} \%$ & $\mathbf{2 6} \%$ & $\mathbf{3 3} \%$ & $\mathbf{4 4} \%$ & $\mathbf{5 3 \%}$ & $\mathbf{6 5} \%$ \\
\hline Non-titled & 93 & 110 & 117 & 153 & 189 & 233 \\
\hline doctors & 23 & 29 & 40 & 63 & 93 & 137 \\
\hline Proportion of doctors & $\mathbf{2 5 \%}$ & $\mathbf{2 6} \%$ & $\mathbf{3 4} \%$ & $\mathbf{4 1} \%$ & $\mathbf{4 9} \%$ & $\mathbf{5 9} \%$ \\
\hline
\end{tabular}

The remarkable increase in the number of doctorates among senior officials (from $20 \%$ in 1890 to $51 \%$ in 1910 and $62 \%$ in 1918) confirms the realization of the performance principle (Leistungsprinzip) at the highest levels of the administration. Yet considerable variations between the different ministries can be observed. While academic titles were quite rare in the Ministry of Agriculture (the very one in which the nobility was over-represented), doctorates dominate the Ministries of Justice ( $72 \%$ in 1910) and of Religious Affairs and Education $(68 \%)$. Besides, this tendency differently affected nobility and commoners, as can be seen in Table 6 . After the promulgation of the qualification law, commoners were the first to massively invest in the higher academic degree and the proportion of doctors was higher among them then among the historical orders (19-16\% in 1885 and $25-18 \%$ in 1890). These statistical regularities can be interpreted as a way to strategically compensate the symbolical capital of nobility, and present an obvious argument to support the theory of professionalization as a way to gentrification. Yet surprisingly, a trend reversal is to be observed at the turn of the century: the proportion of doctors among the nobility caught up with commoners, and even gradually exceeded it (44-41\% in 1905, then 53-49\% and 65$59 \%$ during the war). This very reversal highlights the reconversion of a traditional elite into a meritocratic one, possessing both noble and academic titles simultaneously. Unfortunately, there are no university statistics recording the social status of the students, in order to evaluate if these evolutions are caused by changes in the social composition of the student body. Still, at the turn of the century the percentage of doctors was higher among commoners than among the nobility, implying, too, that the new generation arriving in the higher ranks had a different profile.

Another interesting aspect to measure is the effect of an academic title on careerspeed (Table 7).

Table 7: Age at the time of promotion in the higher ranks according to academic title, 1885-1918

\begin{tabular}{|c|c|c|c|c|c|c|c|c|c|}
\cline { 2 - 10 } \multicolumn{1}{c|}{} & \multicolumn{3}{|c|}{ VII. Ministerial-Sekretäre } & \multicolumn{3}{c|}{ VI. Sektions-Räte } & \multicolumn{3}{c|}{ V. Ministerial-Räte } \\
\cline { 2 - 10 } & Average & Doctors & $\begin{array}{c}\text { Non- } \\
\text { titled }\end{array}$ & Average & Doctors & $\begin{array}{c}\text { Non- } \\
\text { titled }\end{array}$ & Average & Doctors & $\begin{array}{c}\text { Non- } \\
\text { titled }\end{array}$ \\
\hline $1886-1895$ & 37 & 35 & 38 & 43 & 42 & 43 & 50 & 52 & 50 \\
\hline $1896-1905$ & 39 & 37 & 43 & 45 & 43 & 47 & 51 & 50 & 51 \\
\hline $1906-1918$ & 39 & 38 & 41 & 45 & 43 & 48 & 51 & 49 & 54 \\
\hline
\end{tabular}


Whereas noble titles have no impact in terms of rapidity of advancement (Table 5), academic titles present a valuable asset in this regard. Civil servants with a doctoral degree reach rank VII three to six years earlier than their colleagues without an academic title. Yet this first advantage is gradually vanishing all along the career: doctors are still slightly younger when promoted in the upper ranks, but it takes them longer to reach the top of the hierarchy (17 against 12 years in 1886-1895), and the discrepancies observed in rank VII is by far reduced in rank. The results of this research cannot explain this ambiguous situation (statistical incoherence or external factors not taken into account?), but this effect reverses soon, as it takes only eleven years for doctors to reach rank $\mathrm{V}$ against 13 for non-doctors in 1910 .

The practice of ennobling senior officials was a specific way to harmonize a 'meritocratic' with a more traditional elite. Indeed, sanctioning arrival at a superior level of the hierarchy with a title of nobility can be seen as an attempt to conciliate the traditional representation of society with the needs of a modern state apparatus. ${ }^{37}$ Ennobled senior officials account for $10 \%$ of the study sample (Table 3 ). Indeed, this practice of ennoblement paradoxically increased after the $1890 \mathrm{~s}$, at the very time when a title of nobility no longer offered any advantage in the promotion system (Table 5): $80 \%$ of all ennoblements of ministerial civil servants during the dualist era occurred after $1890^{38}$. Was this practice a neoaristocratization of the administration, as in Prussia or in Austria, or perhaps an attempt to compensate for the mass arrival of non-titled commoners at the top of the bureaucratic hierarchy?

Table 8: Distribution of noble and ennobled senior officials in the different ministries, 1890-1910

\begin{tabular}{|c|c|c|c|c|c|c|}
\hline \multirow[b]{2}{*}{ Office of Prime Minister } & \multicolumn{2}{|c|}{ Senior officials } & \multicolumn{2}{|c|}{ nobles* } & \multicolumn{2}{|c|}{ ennobled } \\
\hline & 29 & $4 \%$ & 14 & $4 \%$ & 4 & $6 \%$ \\
\hline His Majesty & 12 & $2 \%$ & 8 & $2 \%$ & 3 & $4 \%$ \\
\hline Interior & 130 & $18 \%$ & 71 & $18 \%$ & 7 & $10 \%$ \\
\hline Religious Affairs and Ed. & 59 & $8 \%$ & 39 & $10 \%$ & 3 & $4 \%$ \\
\hline Justice & 46 & $6 \%$ & 23 & $6 \%$ & 6 & $9 \%$ \\
\hline Finance & 169 & $24 \%$ & 88 & $22 \%$ & 14 & $20 \%$ \\
\hline Commerce & 138 & $19 \%$ & 82 & $21 \%$ & 15 & $21 \%$ \\
\hline Agriculture & 111 & $16 \%$ & 77 & $19 \%$ & 15 & $21 \%$ \\
\hline Defense & 56 & $8 \%$ & 28 & $7 \%$ & 6 & $9 \%$ \\
\hline TOTAL $* *$ & 709 & $100 \%$ & 396 & $100 \%$ & 70 & $100 \%$ \\
\hline
\end{tabular}

Some ministries tend to ennoble more than others, regardless of the actual proportion of nobles among them (Table 8). This is the case for example of the Ministry of Justice, comprising $6 \%$ of all senior officials as well as $6 \%$ of all nobles, but $9 \%$ of all ennobled ones. The Ministry of Agriculture shows the same pattern: $16 \%$ of all senior officials, proportionately more nobles $(19 \%)$, but $21 \%$ of the ennoblements. On the contrary, the

\footnotetext{
${ }^{37}$ The ennoblement of senior officials stresses the importance of the traditional sources of prestige in the society as a whole, beyond the bureaucracy. Academic degrees also conferred social status and privileges: a Gymnasium graduation (Matura) automatically awarded the status of gentleman (úr) and the right to carry a sword, to vote, and opened the way to one-year volunteer military service (the requirement for becoming a reserve officer). Besides, college and university graduates had been addressed as 'tekintetes' since the beginning of the Dualist era.

${ }^{38}$ BAVOUZET 2017, 443.
} 
Ministry of the Interior presents the opposite tendency: it comprises $18 \%$ of all senior officials and among them the same proportion of nobles, but only $10 \%$ of the ennobled civil servants. Ennoblement thus does not seem to operate as a corrective of a too 'bourgeois' social composition, but to reinforce the presence of nobility in the already 'nobles' ministries.

The ennoblement of senior officials often went along with magyarizing the surname, and, in the case of the very few Jews in the sample, even with religious conversion. ${ }^{39}$ This should draw the attention on the symbolic changes in ennobling civil servants, in a time of massive magyarization politics first targeting the administration. The historical purpose of this practice, rewarding outstanding competencies by elevation into the traditional elite, tends to be gradually replaced by another function: assimilation into the official elite, the natio Hungarica (with a joint meaning of noble and Hungarian, i.e. Magyar nation). In this sense, ennoblement of Konzeptsbeamte appears a lot less anachronistic.

\section{Conclusion}

To summarize the results of this inquiry on the Hungarian ministerial elite, the two defined variables (noble and academic title) provided by the Staatshandbücher allowed to measure the increasing number of doctors and the repercussions of an academic title on career achievement. Also, the remnants of traditional mechanisms at the very heart of the bureaucratic machinery could be measured as well, still somehow favoring nobility and rewarding meriting commoners with ennoblement. Therefore, the sociological evolution of the Konzeptsdienst should not be seen as a clear-cut replacement of an older generation committed to feudal values by modern bourgeois dignitaries (Honoratioren), whose accomplishments were entirely based on their merits. Indeed separating the ideal-type of an ancien regime society from a modern capitalist one may help to distinguish the basic differences, but fails to consider the full sweep and ambiguity of the movement of modernization: from a traditionalist elite, yet aware of the importance of academic titles, to a meritocratic elite, yet benefiting from traditional sources of prestige (ennoblement, terms of address).

Senior officials of Hungarian ministries offer a relevant example of the conversion of a traditional elite into a modern one bearing meritocratic ideals. But this conversion, which occurred at a critical juncture in history at the turn of the $19^{\text {th }}$ and the $20^{\text {th }}$ century, requires a special degree of insight in order to be correctly perceived. As mentioned in the introduction of this volume ${ }^{40}$, the actual revival of interest in imperial Austrian and Habsburg administration is mainly taking the form of individual or collective biography -also reflected in this volume. A biographical approach, focusing on individual actors more than on institutions or general social considerations, offers empirical insights in an often comparative perspective of different levels of the bureaucracy. Yet this essay hopes to contribute to reassert the value of a quantitative approach of this problematic. Indeed, statistical analysis conducted in this paper helped to highlight the broadening of sociological recruitment as well as some aspects of the professionalization of the Konzeptsdienst, in a humbler and more reduced way than the social historical approach that stamped its mark on Austrian historiography (symptomatically no statistics are to be found in Heindl's work). Still, regarding the conclusive results obtained by measuring only two variables, we cannot but

\footnotetext{
${ }^{39}$ Among the 70 ennobled senior officials of our survey, 40 had non-Magyar, mostly German surnames. Half of them magyarized their name. This proportion surpasses by far the general proportion of magyarization of names in the sample (14\% of the non-Magyar surnames, i.e. 44 of 310 individuals).

${ }^{40}$ See Adlgasser's and Lindström's contribution to this volume. For the success of the biographical approach, see also LINDSTRÖM 2008.
} 
insist on the heuristic input of reintroducing a quantitative approach alongside the empirical preoccupations of the actual historiography.

\section{Bibliography}

BAVOUZET J.A., Entre technocrates et administrateurs de l'Ancien Régime. Les hauts fonctionnaires des ministères hongrois du dualisme (1867-1918), Université Paris Ouest-Nanterre, Paris-Nanterre, 2017.

BENEDEK G., « Die Beamten in Ungarn », H. RUMPLER et P. URBANITSCH (dir.), Soziale Strukturen. Von der Feudal-Agrarischen zur Bürgerlich-industriellen Gesellschaft, Wien, Verlag der Österreichischen Akademie der Wissenschaften, coll.« Die Habsburgermonarchie (1848-1918)», 2010, vol. XI/IX/I, p. 1211-1243.

BENEDEK G., «A dualizmus kori tisztviselők lakásviszonyainak történetéhez », A felhalmozás míve. Történeti tanulmányok Kövér György tiszteletére, Budapest, Századvég Kiadó, 2009, p.

BENEDEK G., « Képesítési elöírások a magyar közigazgatásban a 19. század második felében », Életünk Kelet-Európa. Tanulmányok Niederhauser Emil 8o. születésnapjára, Budapest, 2003, p. 36-41.

BENEDEK G., Dzsentri és Bach-huszár. Társadalomtörténeti vizsgálatok a neoabszolutizmus- és a dualizmuskori tisztviselőkről, Budapest, Kandidátusi értekezés, 1997.

BENEDEK G., « Die Verbürgerlichung der ungarischen Ministerialbeamten in der Epoche des Dualismus », Bürgertum in der Habsburgermonarchie, Wien - Köln, 1990, p. 142-148.

CSAPO C., «Életrajz és mentalitás. Ráday Gedeon elfelejtett élete », AETAS-Történettudományi folyóirat, 2002, n ${ }^{\circ}$ 2-3, p. 54-82.

GYANI G. et G. KÖVER, Magyarország társadalomtörténete a reformkortól a második világháborúig], Budapest, Osiris, 2006.

GYANI G. et G. KÖVER, Magyarország társadalomtörténete a reformkortól a második világháborúig, Budapest, Osiris, 1998.

HADOBÁS E., «The Register of Students as a Source », Practice and Theory in Systems of Education, 2008, vol. 3, no 3-4.

HAJDÚ T., Tisztikar és középosztály 1850-1914 : Ferenc József magyar tisztjei, História, 1999.

HEINDL W., Josephinische Mandarine : Bürokratie und Beamte in Österreich, Böhlau, 2013, vol.2.

IVANYI E., Magyar minisztertanácsi jegyzőkönyvek az első világháború korából: 1914-1918, Budapest, Akadémia Kiadó, 1960.

JANOS A.C., The Politics of Backwardness in Hungary, 1825-1945, Princeton, Princeton University Press, 1982.

KARADY V., « Une "nation de juristes". Des usages sociaux de la formation juridique dans la Hongrie d'Ancien Régime », Actes de la recherche en sciences sociales, 1991, vol. 86, n 1, p. 106-124.

KEMPELEN B., Magyar nemes családok, Budapest, Grill Károly Könyvkiadóvállalata, 1911, vol. 11/.

KENYERES Á., Magyar életrajzi lexikon 1000-1990, Budapest, Akadémiai kiadó, 1967, vol. III/.

KOVACS I.G., Elitek és iskolák, felekezetek és etnikumok - Társadalom- és kultúratörténeti tanulmányok, Budapest, L'Harmattan, 2011. 
LADIK G., A közszolgálati alkalmazottak jogviszonyai [Règlement du personnel du service public], Budapest, 1908.

LAKATOS E., A magyar politikai vezetöréteg, 1848-1918. Társadalomtörténeti tanulmány, Budapest, 1942.

LINDSTRÖM F., Empire and identity: biographies of the Austrian state problem in the late Habsburg empire, Purdue University Press, 2008.

NOFlatscher H., «Hofstaatsverzeichnisse, Hof- und Staatssch ematismen », W. PARAVICINI, J. HIRSCHBIEGEL et WEITLAUFER (dir.), Höfe und Residenzen im spätmittelalterlichen Reich. Hof und Schrift, Ostfildern, Jan Thorbecke Verlag, 2007, p. 409-431.

PATYI G., Z. SimON, L. SzÖGI, J. VARGA, et M. SZABÓ, Magyarországi diákok bécsi egyetemeken és főiskolákon, 1867-1890 , Budapest, ELTE Levéltár, coll.« Magyarországi diákok egyetemjárása az újkorban », n²2, 2015.

SOMOGYI É., « Professionalisierung und Veränderungen der nationalen Identität von ungarischen Beamten im gemeinsamen Ministerium des Äußern. Teil 1: Professionalisierung als Vorbedingung und Symptom der Verbürgerlichung im diplomatischen Diens », Mitteilungen des Instituts für Österrechische Geschichtsforschung, 2010, nº 118, p. 140-167.

SOMOGYI É., « Im Dienst der Monarchie oder der Nation? Ungarische Fuhrungsbeamte am Ballhausplatz », Österreichische Osthefte, 2002, vol. 44, 3/4, p. 595-626.

SOMOGYI É., Kormányzati rendszer a dualista Habsburg Monarchiában: a közös minisztertanács, 1867-1906, Budapest, História, 1996, vol.8.

SZEKELY V., A központi államigazgatás tisztségviselői a dualizmus korában : Magyar Királyi Pénzügyminisztérium, Budapest, Magyar Országos Levéltár, coll.« Forrástudományi segédletek », 1985, vol.3.

SZEKELY V., A központi államigazgatás tisztségviselői a dualizmus korában : M. Kir.

Miniszterelnökség, a Király személye körüli M. Kir. Minisztérium, M. Kir. Belügyminisztérium, Budapest, Magyar Országos Levéltár, coll.« Forrástudományi segédletek », 1980, vol.2.

SZEKELY V., A központi államigazgatás tisztségviselői a dualizmus korában : Magyar Királyi Honvédelmi Minisztérium, Budapest, Magyar Országos Levéltár, coll.« Forrástudományi segédletek », 1979, vol.1.

SZINNYEI J. et V. HoRANSZKY, Magyar írók élete és munkái, Budapest, Akadémia Kiadó, 1891, vol. $\mathrm{I}-\mathrm{XIV} /$.

SzÖGI L. et J.M. KISS, Magyarországi diákok bécsi egyetemeken és föiskolákon, 1849-1867, Budapest, ELTE Levéltár, coll.« Magyarországi diákok egyetemjárása az újkorban », n 7, 2003.

SzÖGI L., A. MESZAROS, et J. VARGA, Magyarországi diákok a Habsburg Birodalom kisebb egyetemein és akadémiáin 1789-1919, Budapest, ELTE Levéltár, coll.« Magyarországi diákok egyetemjárása az újkorban », n² 21, 2014.

URBANiTsCh P., «The High Civil Service Corps in the Last Period of the Multi-Ethnic Empire between National and Imperial Loyalties », Historical Social Research/Historische Sozialforschung, 2008, p. 193-213.

Révai Nagylexikon, Budapest, Révai Testvérek Irodalmi Intézet R.t., 1911, vol. I-XXI/.

A magyar királyi Pénzügyminisztérium ügykörre vonatkozó szolgálati szabályok gyüjteménye, Budapest, 1874. 
A Magyar Királyi Pénzügyminisztérium ügykörére vonatkoző szolgálati szabályok gyüjteménye (Pénzügyi Szolgálati Szabályzat), Budapest, M. Kir. Pénzügyminisztérium, 1874.

Hof- und Staastshandbuch des Kaiserthum Österreich.

Magyaroszág tiszti cim- és névtára.

Libri Regii - Királyi Könyvek. 